\title{
Genetics of galactose utilisation via the Leloir pathway in lactic acid bacteria
}

\author{
Benoît Grossiord ${ }^{\mathrm{a}}$, Elaine E. Vaughan ${ }^{\mathrm{b}}$, Evert Luesink ${ }^{\mathrm{a}}$, \\ Willem M. de Vos ${ }^{\text {a,c* }}$
}
${ }^{a}$ Microbial Ingredients Section NIZO, P.O. Box 20,6710 BA Ede, the Netherlands
${ }^{b}$ Nestlé Research Center, Nestlé Ltd., Vers-chez-les-Blancs, P.O. Box 44, 1000 Lausanne, Switzerland
${ }^{c}$ Laboratory of Microbiology, Department of Biomolecular Sciences, Wageningen Agricultural University, the Netherlands

\begin{abstract}
Lactic acid bacteria (LAB) are used in industrial dairy fermentations mainly for the conversion of lactose into lactic acid. While the glucose moiety of lactose is metabolised via the well-known glycolysis, two distinct pathways, the tagatose-6P pathway or the Leloir pathway, can be used for degradation of the galactose moiety. The Leloir pathway enzymes include galactokinase (GalK), galactose-1P uridylyltransferase (GalT) and UDP-galactose 4-epimerase (GalE) which are responsible for the conversion of galactose to glucose-1P. Several of these enzymes have been characterised in different LAB. They are chromosomally encoded and their genes are organized in clusters. Here, we present and discuss the characteristics of the gal gene clusters of several LAB including Lactococcus lactis, Leuconostoc lactis, Lactobacillus helveticus, Lactobacillus casei and Streptococcus thermophilus. Whereas the degree of identity between the deduced primary sequences of the described Leloir pathway enzymes is very high, the genomic organisation of the clusters together with their mechanisms of regulation are variable and species-specific. Studies of the different factors involved in the control of lactose and galactose utilisation in these LAB will allow the development of new strategies to engineer their efficient utilisation in industrial dairy fermentations. (C) Inra/Elsevier, Paris.
\end{abstract}

\section{lactic acid bacteria / galactose / metabolism / Leloir pathway / genetics}

Résumé - Déterminants génétiques de l'utilisation du galactose par la voie de Leloir chez les bactéries lactiques. La principale fonction des bactéries lactiques (BL) en industrie laitière est la conversion du lactose, principal sucre du lait, en acide lactique. Le métabolisme de ce disaccharide par les BL nécessite la dégradation d'au moins une de ses deux moitiés, glucose ou galactose. Alors que le glucose est dégradé par la voie de la glycolyse, deux voies de catabolisme du galactose ont été mises en évidence chez les BL. Il s'agit de la voie du tagatose-6P, impliquée dans la dégradation du galactose-6P et de la voie de Leloir spécifique du galactose. Les enzymes de la voie de Leloir, la galactokinase (GalK), la galactose-1P uridylyltransférase (GalT) et l'UDP-galactose 4-épimerase (GalE) sont impliquées dans la

* Correspondence and reprints 
conversion du galactose en glucose-1P et ont été caractérisées chez plusieurs BL. Les gènes galK, galT, et galE codant pour ces enzymes chez les BL sont situés sur le chromosome bactérien et organisés en groupes formant des unités génétiques spécifiques. Nous présentons et discutons le clonage, l'organisation et l'expression des gènes gal de plusieurs BL incluant Lactococcus lactis, Leuconostoc lactis, Lactobacillus helveticus, Lactobacillus casei et Streptococcus thermophilus. La comparaison des différents groupes de gènes gal présents chez ces BL et incluant galK, galT et galE montre un degré d'identité très élevé, alors que leurs organisations chromosomiques et leurs systèmes d'expression sont spécifiques pour chaque espèce. L'étude des systèmes d'expression des gènes gal et de la régulation des mécanismes impliqués dans l'utilisation du lactose ou du galactose par les BL permet d'envisager le développement de nouvelles stratégies visant à contrôler et maîtriser l'utilisation efficace de ces sucres en industries alimentaires et laitières. (C) Inra/Elsevier, Paris.

bactéries lactiques / galactose / métabolisme / voie de Leloir / génétique

\section{INTRODUCTION}

The main function of lactic acid bacteria $(\mathrm{LAB})$ in industrial dairy fermentations is the conversion of lactose into lactic acid. The catabolism of the disaccharide lactose involves the degradation of its two moieties, glucose and galactose. LAB have developed two different strategies to metabolise lactose or galactose that depend on their mode of transport, which is either via the phosphoenolpyruvate-dependent phosphotransferase system (PEP-PTS) or via a permease system $[11,28]$ (see figure l). Transport of lactose or galactose via the PEP-PTS results in phosphorylated galactose, which is metabolised by the enzymes of the tagatose- $6 \mathrm{P}$ pathway that include galactose-6-P isomerase ( $\mathrm{LacAB}$ ), tagatose-6-P kinase ( $\mathrm{LacC}$ ) and tagatose1,6diP aldolase (LacD) [29] (figure 1). In the case of entry via a permease, the sugar is not modified and the galactose is catabolised via the Leloir pathway. Before entering these two different pathways, lactose needs to be hydrolysed by either a phospho- $\beta$-galactosidase ( $\mathrm{LacG}$ ) generating glucose and galactose- $6 \mathrm{P}$, or a $\beta$-galactosidase (LacZ or LacLM) generating glucose and galactose (figure 1). The Leloir pathway is one of the first discovered central metabolic pathways, established by L.F. Leloir and coworkers in the early fifties, and has been recently reviewed [12]. It includes three enzymes, galactokinase (EC 2.7.1.6, GalK), galactose-1-P uridylyltransferase (EC 2.7.7.10, GalT) and UDP-galactose 4-epimerase (EC 5.1.3.2, GalE), which are involved in the conversion of galactose to glucose-1-P (figure 1) and are encoded by the gal genes.

\section{MOLECULAR ORGANISATION OF THE GALACTOSE GENE CLUSTERS IN LAB}

In recent years, a number of gal genes involved in the Leloir pathway have been characterised in seven different $\mathrm{LAB}$ from four different genera (figure 2). All seem to be clustered in one or more gal gene clusters and their molecular organisation and main characteristics are described below with specific attention for their cloning, expression and sequence comparison.

\subsection{Galactose transport and metabolism in Lactococcus lactis}

Lactococcus lactis strains are known to be able to use galactose via either the Leloir pathway or the tagatose-6P pathway $[27,28]$. For the utilisation of galac- 


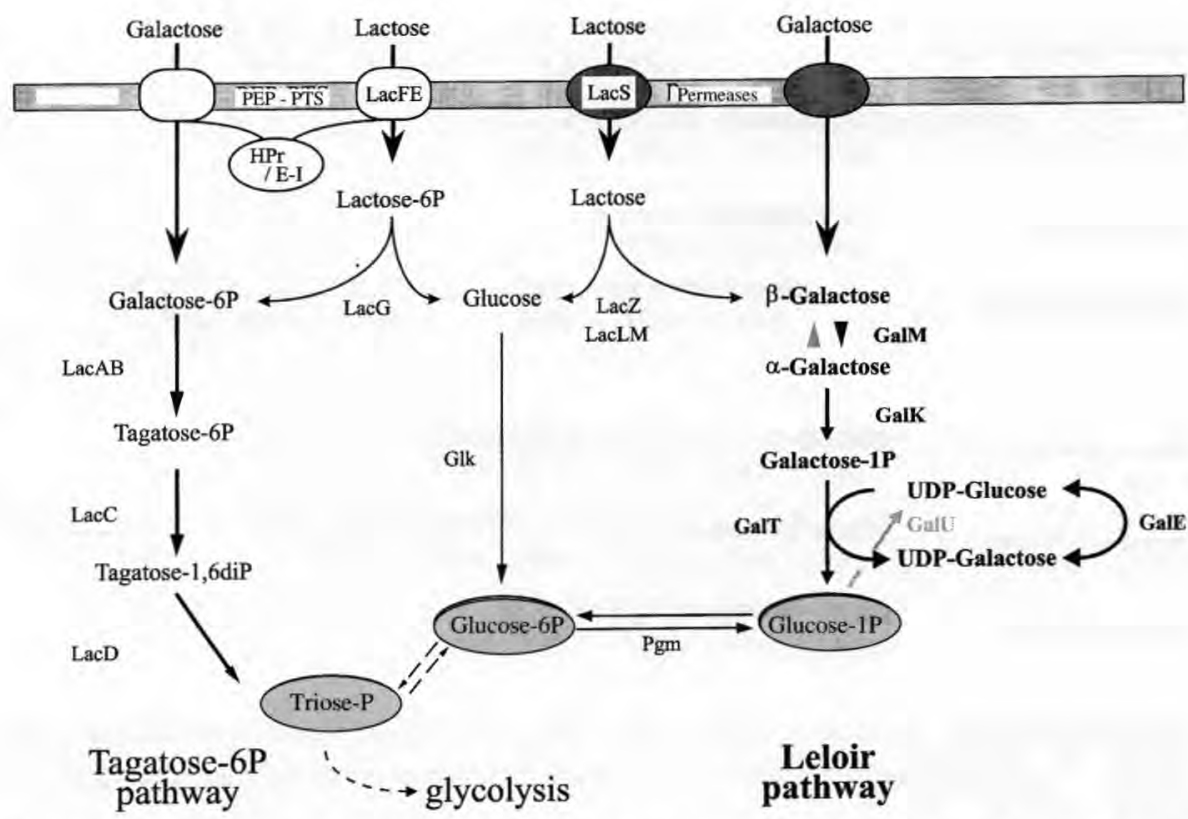

Figure 1. Possible pathways and enzymes used for utilisation of lactose and galactose in LAB. E-I, enzyme I; HPr, histidine-containing phosphocarrier protein; LacS, lactose permease; Glk, glucokinase; Pgm, phosphoglucomutase; GalU, UDP-glucose pyrophosphorylase; LacG, LacZ, LacLM, GalM, GalK, GalT, GalE, LacAB, LacC, LacD, see text; LacFE, lactose PTS enzymes.

Figure 1. Voies enzymatiques possibles impliquées dans l'utilisation du lactose et du galactose par les bactéries lactiques. E-I, enzyme I ; HPr, protéine phosphotransporteur à histidine ; lacS, lactose permease ; Glk, Glucokinase ; Pgm, Phosphoglucomutase; GalU, UDP-Glucose pyrophosphorylase ; LacG, LacZ, LacLM, GalM, GalK, GalT, GalE, LacAB, LacC, LacD, voir texte ; LacFE, enzymes PTS lactose.

tose via the Leloir pathway, a highly specific galactose permease system with low affinity for lactose has been described and suggested that the Leloir pathway represents the major route for galactose utilisation at low concentrations of extracellular sugar [28]. Up to now, gal genes have been characterised in two different strains of Lactococcus lactis, ATCC 7962 and MG1363.

\subsubsection{The galactose-lactose gene cluster of Lactococcus lactis ATCC 7962}

The atypical, non-dairy lactococcal strain ATCC 7962 has been used in studies on the transport of lactose in LAB and has been instrumental in the discovery of a proton-coupled galactoside transport system [19]. As its affinity for galactose is higher than for lactose, this transporter system is likely to be a galactose permease. Another interesting feature of this strain is the presence of a highly regulated $\beta$-galactosidase activity of which the encoding gene has been cloned in $E$. coli by complementation of the lacZ DM15 mutation $[15,25]$. Sequence analysis of the cloned fragment led to the identification of two gal genes flanking the lacA (homologous to the $E$. coli thiogalactosidase gene) and lac $Z$ (encoding the $\beta$-galactosidase) genes $[14,15,25]$. Upstream and downstream of the tandem $\operatorname{lac} A Z$ genes whose deduced amino-acid sequences showed similarity to previously characteri- 


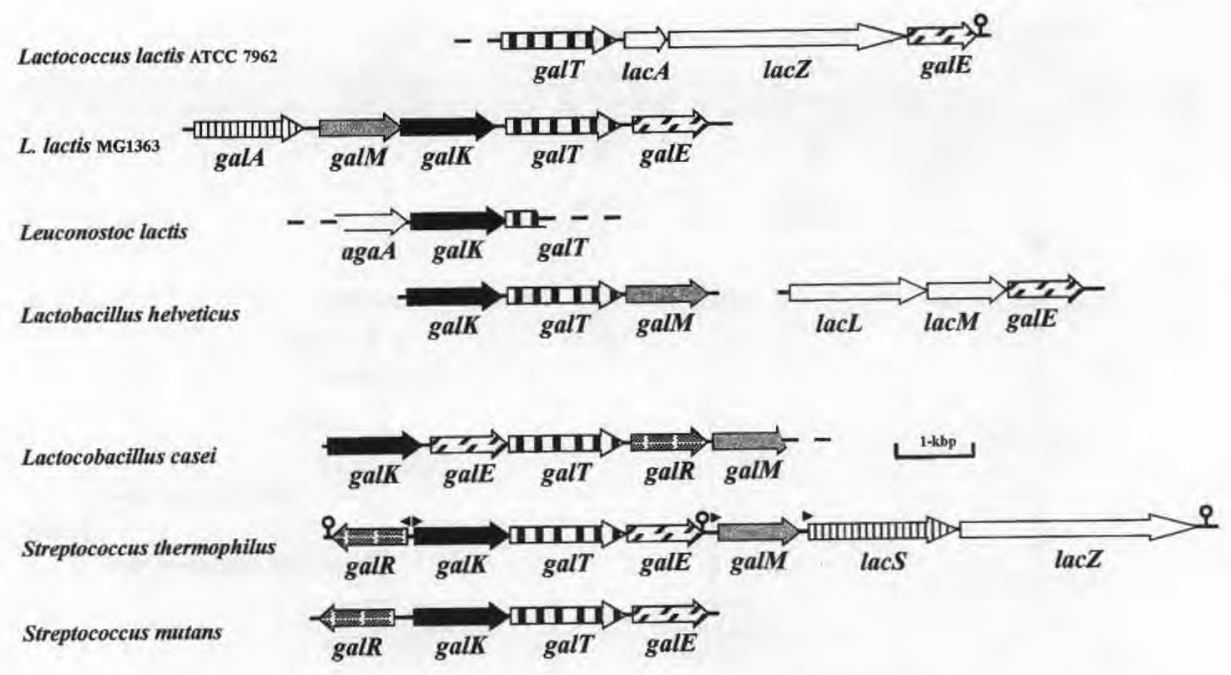

Figure 2. Schematic outline of the genetic organisation of the gal gene clusters from different LAB. Figure 2. Représentation schématique de l'organisation des gènes gal de différentes bactéries lactiques.

sed galT (encoding the galactose-1P uridylyltransferase) and galE (encoding the UDP-galactose 4-epimerase) genes, respectively, were located ([25] personal communication). A remarkable feature of this Lactococcus lactis gene cluster is that it contains both lactose and galactose genes (figure 2).

\subsubsection{The galactose operon of Lactococcus lactis MG1363}

Lactococcus lactis MG1363 [13], is a plasmid-free derivative of the genetically well-characterised strain Lactococcus lactis NCDO 712 which is able to use galactose via the Leloir pathway. The cloning of its galactokinase gene ( $\mathrm{g} a \mathrm{lK}$ ) resulted in the discovery of the gal gene cluster of this lactococcal strain (Grossiord et al, in preparation) (figure 2). The genes for the Leloir pathway, galK, galT and galE are preceded by the galM gene encoding a putative mutarotase and the galA gene encoding a permease, likely to transport galactose. The mutarotase (EC 5.1.3.3,
GalM) catalyses the interconversion of the $\alpha$ - and $\beta$-anomers of galactose $[3,12,24]$. The presence of GalM activity was found to be essential for efficient lactose utilisation in $E$. coli as the cleavage of this $\beta$-galactoside by $\beta$-galactosidase gives glucose and $\beta$-D-galactose where as $\alpha$-D-galactose is the only substrate for GalK (figures 1, 2) [3]. The gene order of this novel gal cluster differs from the other laclgal gene clusters reported so far and suggests an operon-like organisation (galAMKTE, figure 2). A unique feature of this cluster is that its gene order reflects that of the biochemical reactions involved in the degradation of galactose via the Leloir pathway (figures 1,2).

\subsection{The galK gene cluster of Leuconostoc lactis NZ6009}

Several lactose genes from the mesophilic Leuconostoc lactis have already been characterised and are located on the lactose plasmid pNZ63 [7-9, 31]. In 
contrast, the galactose genes are chromosomally encoded [31]. The galK gene from Leuconostoc lactis has been cloned by complementation of a GalK-deficient strain E. coli HB101 (Vaughan et al., unpublished data). Partial sequence analysis of the DNA flanking galK revealed an open reading frame (ORF) upstream with homology to an $\alpha$-galactosidase gene $(\operatorname{ag} a A)$ and a downstream ORF with homology to galT genes from other LAB (figure 2).

\subsection{Two galactose gene clusters in Lactobacillus helveticus}

Lactobacillus helveticus, in contrast to some other galactose-negative lactobacilli such as Lactobacillus bulgaricus, is able to use galactose via the Leloir pathway [17, 30]. Initially, most attention was focused on the genetic analysis of its split $\beta$-galactosidase genes analogous to the situation in Leuconostoc lactis [9, 34] (figure 2). Further analysis led to the identification of the galE gene [34] (figure 2). The galK and galT genes from two different Lactobacillus helveticus strains have also been cloned and characterised $[20,30]$. These two genes are arranged in tandem and are probably organised as an operon transcribed from a promoter located upstream of galK. Further sequence analysis of the cloned fragment revealed the presence of the galM gene downstream of galT, which could encode a mutarotase with homology to GalM from Streptococcus thermophilus [20]. Therefore, Lactobacillus helveticus shows an original organisation of its gal genes since they are separated on the chromosome: a cluster with a possible operon structure contains the galK, galT and galM genes, while the galE gene is within another locus, downstream of the lac $L M$ genes encoding the $\beta$-galactosidase (figure 2).

\subsection{The galactose gene cluster of Lactobacillus casei $64 \mathrm{H}$}

Lactobacillus casei $64 \mathrm{H}$ contains a 35-kb lactose plasmid, pLZ64 which has been studied in detail $[5,6]$. This strain $64 \mathrm{H}$ is also able to grow on galactose as a carbon source, using either the Leloir pathway or the tagatose-6P pathway [2]. Recently, the genes coding for the galactokinase and other enzymes of the Leloir pathway have been cloned in E. coli [2]. Sequence analysis and homology comparison suggested the presence of a gal gene cluster with the order galKETRM (figure 2). The galR gene product shows homology with members of the GalR-LacI family of bacterial transcriptional regulators which bind as a dimer to the operator sequence and need a particular effector molecule for their specific regulatory function [22, 32,33 ]. The galM gene possibly encodes a mutarotase, an enzyme also found in Lactobacillus helveticus [20], Streptococcus thermophilus [24] and Lactococcus lactis MG1363 (Grossiord et al., in preparation). The genetic order of this galactose cluster is unique among the gal operons and is the first example in $\mathrm{LAB}$ of a possible regulatory gene encoded within the galactose cluster that is oriented in the same direction as the other gal genes.

\subsection{The galactose-lactose gene cluster of Streptococcus thermophilus}

Most of the dairy strains of Streptococcus thermophilus are unable to ferment lactose completely and only use the glucose moiety of the sugar [18]. The galactose moiety is released to the medium by the lactose permease LacS which functions as a lactose/galactose exchanger [23]. The genes encoding the lactose permease (lacS) and the $\beta$-galactosidase (lacZ) have been cloned and sequenced $[16,26]$. Analysing the sequences flanking the lac operon (lacSZ) of Streptococcus thermophilus 
A147, the galE and gal $M$ genes were discovered [24] (figure 2). Another report described the cloning of the galK gene from the galactose-fermenting strain Streptococcus thermophilus F410 by complementation of a GalK-deficient $E$. coli strain [21]. Interestingly, it was discovered recently that the non-galactose fermenting strain Streptococcus thermophilus CNRZ 302 contains the intact genes galKTE coding for the Leloir pathway enzymes (figure 2), but that these genes are not transcribed [4]. Galactose-fermenting mutants where obtained and appeared to express the $\mathrm{gal}$ genes as a result of mutations in the gal promoter region [4]. The expression of these $\mathrm{gal}$ genes is under the control of the regulator GalR, which probably acts together with galactose or a derivative as an inducer complex [10]. Transcription of the galR gene is under control of its own promoter whose activity is regulated by glucose and lactose [4]. The gal operon of Streptococcus thermophilus shows the same organisation as was described for Streptococcus mutans, with the genetic order galRKTE [1], where the regulatory gene is transcribed in the opposite direction compared with the structural genes galKTE (figure 2). As the complete utilisation of galactose is a desirable property in various industrial dairy fermentations, the elucidation of the transcriptional regulation of the gal genes encoding the Leloir pathway enzymes in non-galactose fermenting Streptococcus thermophilus could provide new strategies to obtain stable galactose-fermenting mutants.

\section{CONCLUDING REMARKS}

When considering the gal genes and their products identified in LAB, a high degree of similarity is evident (figure 2). Especially the gene products involved in the Leloir pathway, GalK, GalT and GalE are very well conserved among LAB and share a high degree of identity (more than $50 \%$ identity for GalK and GalT, and more than $60 \%$ identity for GalE), which is in line with the close relationship of these microorganisms due to their late separation in the evolutionary process. Alternatively, it can also be a consequence of horizontal transfer of the gal genes. In contrast, when the organisation of the gal genes and their regulation are taken into consideration, no consensus is found. The presence of the gal genes, their location and order on the chromosome are species-specific, and even between strains from the same species important differences are observed (figure 2). Those differences in organisation either suggest that $\mathrm{LAB}$ have developed unique gal gene clusters by recruiting the individual gal genes separately, or may reflect a high genomic plasticity. Although the regulation of expression of the galactose gene clusters has received little attention so far, their transcriptional organisation and possible control allows us to separate them in two groups (figure 2). Some of the gal gene clusters contain a gene, galR, encoding a regulatory protein (Lactobacillus casei, Streptococcus thermophilus and Streptococcus mutans) whereas that gene is not found in the clusters of other species (Lactococcus lactis, Leuconostoc lactis and Lactobacillus helveticus). Understanding of the regulatory processes involved is essential for engineering galactose or lactose utilisation in industrially important LAB.

\section{ACKNOWLEDGMENTS}

We are very grateful to K. Bettenbrock and C. A. Alpert for communicating their results about the organisation of the galactose cluster from Lactobacillus casei $64 \mathrm{H}$ prior to publication. We thank P. Hols, M. Kleerebezem and R. van Kranenburg for critically reading of the manuscript. Part of this work has been supported by 
contracts ERB-CHGT-CT-93-0459 and BIOT-CT-96-0498 of the Commission of European Communities.

\section{REFERENCES}

[1] Ajdié D., Sutcliffe I.C., Russel R.R.., Ferretti J.J., Organization and nucleotide sequence of the Streptococcus mutans galactose operon, Gene, 180 (1996) 137-144.

[2] Bettenbrock K., Alpert CA., Galactose metabolism in Lactobacillus casei is mediated by two distinct pathways. Fifth symposium on Lactic Acid Bacteria, Veldhoven, The Netherlands, Abstract G11 (1996).

[3] Bouffard G.G., Rudd K.E., Adhya S.L., Dependence of lactose metabolism upon mutarotase encoded in the gal operon in Escherichia coli, J. Mol. Biol. 244 (1994) 269-278

[4] Catzeddu P., Vaughan E.E., Deiana P., de Vos W.M., Why Streptococcus thermophilus cannot metabolize galactose, Fifth symposium on Lactic Acid Bacteria, Veldhoven, The Netherlands, Abstract G49 (1996).

[5] Chassy B.M., Alpert C.A., Molecular organisation of the plasmid encoded lactose-PTS of Lactobacillus casei, FEMS Microbiol. Rev. 63 (1989) 157-166.

[6] Chassy B.M., Gibson E.V., Giuffrida A., Evidence for plasmid associated lactose metabolism in Lactobacillus casei subsp. casei, Curr. Microbiol. 1 (1978) 141-144.

[7] David S., Genetics of mesophilic citrate fermenting lactic acid bacteria, $\mathrm{PhD}$. Thesis, Wageningen Agricultural University, Wageningen (1992).

[8] David S., Simons G,, de Vos W.M., Plasmid transformation by electroporation of Leuconostoc paramesenteroides and its use in molecular cloning, Appl. Environ. Microbiol. 55 (1989) 1483-1489.

[9] David S., Stevens H., van Reil M., Simons G., de Vos W.M., Leuconostoc lactis $\beta$-galactosidase is encoded by two overlapping genes, J. Bacteriol. 174 (1992) 4475-4481.

[10] de Vos W.M., Metabolic engineering of sugar catabolism in lactic acid bacteria, Antonie van Leeuwenhoek 70 (1996) 223-242.

[11] de Vos W.M., Vaughan E.E., Genetics of lactose utilization in lactic acid bacteria. FEMS Microbiol. Rev. 15 (1994) 217-237.

[12] Frey P.A., The Leloir pathway: a mechanistic imperative for three enzymes to change the stereochemical configuration of a single carbon in galactose, FASEB J. 10 (1996) $561-470$.
[13] Gasson M.J., Plasmid complements of Streptococcus lactis NCDO 712 and other lactic streptococci after protoplast-induced curring, J. Bacteriol. 154 (1983) 1-9.

[14] Griffin H.G., Gasson M.J., The gene (lacA) encoding galactoside acyltransferase from Lactococcus lactis, Biotechnol. Lett. 16 (1994) 1125-1130.

[15] Griffin H.G., MacCormick C.A., Gasson M.J., Cloning, DNA Sequence, and regulation of expression of a gene encoding $\beta$-galactosidase from Lactococcus lactis, DNA Sequence 6 (1996) 337-346.

[16] Herman R.E. McKay L.L., Cloning and expression of the $\beta$-D-galactosidase gene from Streptococcus thermophilus, Appl. Environ. Microbiol. 52 (1986) 45-50.

[17] Hickey M.W., Hillier A.J., Jago G.R., Transport and metabolism of lactose, glucose, and galactose in homofermentative Lactobacilli, Appl. Environ. Microbiol. 51 (1986) 825-831.

[18] Hutkins R.W., Morris H.A., Carbohydrate metabolism by Streptococcus thermophilus: a review, J. Food Prot. 50 (1987) 876.

[19] Kashket E.R., Wilson T.H., Proton-coupled accumulation of galactoside in Streptococcus lacis 7962, Proc. Natl. Acad. Sci. U.S.A. 70 (1973) 2866-2869.

[20] Mollet B., Pilloud N., Galactose utilization in Lactobacillus helveticus: isolation and characterization of the galactokinase $(\mathrm{galK})$ and the galactose-1-phosphate uridyl transferase (galT) génes, J. Bacteriol. 173 (1991) 4464-4473.

[21] Mustapha A., Hutkins R.W., Zirnstein G.W., Cloning and characterization of the galactokinase gene from Streptococcus thermophilus, J. Dairy Sci. 78 (1995) 989-997.

[22] Nguyen C.C., Saier M.H.Jr., Phylogenic, structural and functional analyses of the LaclGalR family of bacterial transcription factors, FEBS Lett. 377 (1995) 98-102.

[23] Poolman B., Energy transduction in lactic acid bacteria, FEMS Microbiol. Rev. 12 (1993) 125-148.

[24] Poolman B., Royer T.J., Mainzer S.E., Schmidt B.F., Carbohydrate utilization in Streptococcus thermophilus: characterization of the genes for aldose 1-epimerase (Mutarotase) and UDPglucose 4-epimerase, J. Bacteriol. 172, (1990) 4037-4047.

[25] Pridmore R.D., Richard M., Mollet B., Hottinger $\mathrm{H}$., Cloning, sequencing and expression of the Lactococcus lactis NCDO 2054 lacZ gene. Annual Meeting of the American Society for Microbiology Las Vegas, Abstract O-73 (1991). 
[26] Schroeder C.J., Robert C., Lenzen G., McKay L.L.,Mercenier A., Analysis of the lacZ sequences from Streptococcus thermophilus strains: comparison with the Escherichia coli and Lactobacillus bulgaricus $\beta$-galactosidase sequences, J. Gen. Microbiol. 137 (1991) 369-380.

[27] Thompson J., Lactose metabolism in Streptococcus lactis: phosphorylation of galactose and glucose moieties in vivo, J. Bacteriol. 140 (1979) 774-785.

[28] Thompson J., Galactose transport systems in Streptococcus lactis, J. Bacteriol. 144 (1980) 683-691.

[29] Van Rooijen R.J., van Schalkwijk S., de Vos W.M., Molecular cloning, characterization, and nucleotide sequence of the tagatose 6-phosphate pathway gene cluster of the lactose operon of Lactococcus lactis, J. Biol. Chem. 266 (1991) 7176-7181.
[30] Vaughan E.E., Characterisation of a bacteriocin produced by Lactobacillus helveticus and cloning of chromosomal genes by heterologous complementation, $\mathrm{PhD}$ Thesis, National University of Ireland (1991).

[31] Vaughan E.E., David S., de Vos W.M., The lactose transporter in Leuconostoc lactis is a new member of the LacS subfamily of Galactoside-Pentose-Hexuronide translocators, Appl. Environ. Microbiol. 62 (1996) 1574-1582.

[32] Weickert M.J., Adhya S., A family of bacterial regulators homologous to $\mathrm{gal}$ and $\mathrm{lac}$ repressors, J. Biol. Chem. 267 (1992) 15869-15874.

[33] Weickert M.J., Adhya S., Isorepressor of the gal regulon in Escherichia coli, J. Mol. Biol. 226 (1992) 69-83.

[34] Zwahlen M.C., Mollet B., Characterization of the lacZ gene and discovery of a novel IS element (ISL2) in Lactobacillus helveticus, FEMS Microbiol. Rev. 12, Abstract P27 B9 (1993). 